A Publication of the Materials Research Society

Volume 21, Number 10 ISSN: 0883-7694 CODEN: MRSBEA

ULTRASONIC

NONDESTRUCTIVE

TECHNIQUES FOR

MATERIALS

CHARACTERIZATION

18 Ultrasonic Nondestructive

Techniques for Materials

Characterization

T.E. Matikas and

R.L. Crane, Guest Editors

22 Ultrasonic Characterization of Surfaces and Interphases

S.J. Rokhlin and T.E. Matikas

30 Acoustic Microscopy

for Imaging and

Characterization

A. Briggs and 0 . Kolosov

36 Ultrasonic Force

Microscopy

K. Yamanaka

42 Scanning Electron-Acoustic Microscopy: Do You Know Its Capabilities?

M. Urchulutegui

47 From Photoacoustic

Microscopy to Thermal-

Wave Imaging

R.L. Thomas and L.D. Favro

53 Noncontact Surface-

Hardness Measurement

Using Laser-Based

Ultrasound

A. Safaeinili, A.D.W. McKie, and R.C. Addison, Jr.

\section{IUMRS/MRS NEWS}

58 Preview: 1996 MRS Fall Meeting/ICEM-96

\section{MRS NEWS}

74 Michal I. Freedhoff Appointed OSA/MRS Congressional Fellow for 1996-97

\section{JMR ABSTRACTS}

79 Abstracts for December 1996 Journal of Materials Research

\section{DEPARTMENTS}

\section{Research/Researchers}

11 Washington News

13 Public Affairs Forum

16 Resources

17 Editor's Choice

17 Advertisers in This Issue

75 University Chapter News

76 Upcoming Conference

78 Library

86 Classified

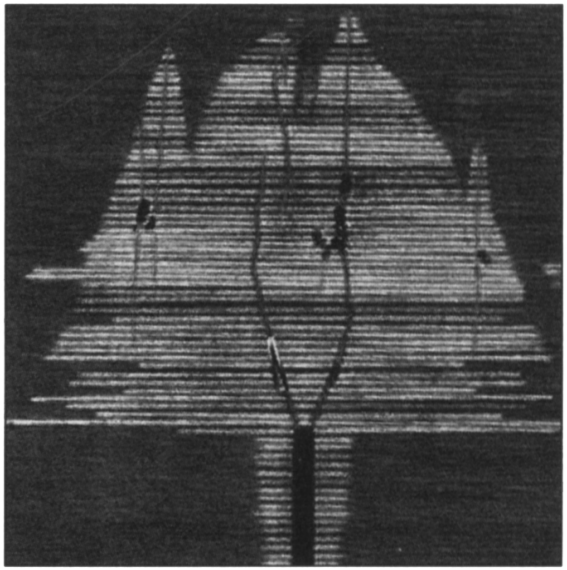

ON THE COVER: An ultrasonic image, based on time-domain scanning acoustic microscopy, of a single-edged, diamond-saw-notch, four-ply, unidirectional, SiC (SCS-6) fiber-reinforced titanium (Ti-15Mo-3Nb-3Al-0.2Si wt \%) matrixcomposite specimen. The specimen was subjected to $10^{4}$ thermomechanical cycles over 36 days. The image indicates that two matrix cracks initiated from the corners of the diamond-saw notch and propagated perpendicular to the fibers and load direction. Further, the ultrasonic image shows the extent of interface oxidation, which has a characteristic mushroom shape. The image shows that the damage occurs after the matrix crack progresses past an unbroken fiber and exposes the interface to environmental attack. The thermomechanicalfatigue test as well as the development of the ultrasonic-characterization technique were performed at the Air Force Materials Directorate, Wright Laboratory, Wright-Patterson Air Force Base, Ohio. For more about this topic, see "Ultrasonic Characterization of Surfaces and Interfaces" by Stanislav I. Rokhlin and Theodore E. Matikas on p. 22. 


\section{About the Materials} Research Society

The Materials Research Society (MRS), a nonprofit scientific association founded in 1973 . promotes interdisciplinary goal-oriented basic research on materials of technological importance. Membership in the Society includes over 12,000 scientists, engineers, and research managers from ind ustrial, government, and university research laboratories in the United States and nearly 50 countries.

The Society's interdisciplinary approach differs from that of single-discipline professional societies because it promotes information exchange across the many technical fields touching materials development. MRS sponsors two major international annual meetings encompassing approximately 60 topical symposia, and also sponsors numerous single-topic scientific meetings. The Society recognizes professional and technical excellence and fosters technical interaction in local geographic regions through Sections and University Chapters.

MRS participates in the international arena of materials research through the International Union of Materials Research Societies (IUMRS). MRS is a member of the Federation of Materials Societies and is an affiliate of the American Institute of Physics.

MRS publishes symposium proceedings, MRS Bulletin, Journal of Materials Research, and other publications related to current research activities.

MRS Bulletin (ISSN: 0883-7694) is published 12 times a year by the Materials Research Society, 9800 McKnight Road, Pittsburgh, PA 15237. Application to mail at periodicals rates has been approved at Pittsburgh, PA and at additional mailing offices. POSTMASTER: Send address changes to MRS Bulletin in care of the Materials Research Society, at the address listed; phone (412) 367-3003; fax (412) 367-4373 Printed in the U.S.A.

Additional copies of articles in MRS Bulletin may be made at $\$ 2.50$ per article. This fee can be paid to the Materials Research Society through the Copyright Clearance Center, Inc 27 Congress Street, Salem, MA 01970.

Membership in MRS is $\$ 75$ annually for regular members, $\$ 25$ for students. Dues include an allocation of $\$ 29$ ( $\$ 17$ for students) to a subscription to MRS Bulletin. Individual member subscriptions are for personal use only. Non-member subscription rates are $\$ 135$ for one calendar year (12 issues) within the US.A and $\$ 185$ elsewhere. Single copies may be purchased for $\$ 16$ each. Send subscription orders to Subscription Department, Materials Research Society, 9800 McKnight Road, Pittsburgh, PA 15237.

MRS Bulletin is included in Current Contonts" Enginecring, Computing, and Technology; Current Contents' / Physical, Chemical, and Earth Sciences, the SciSenrch online database, Re senrch Alert", Science Citation Index, and the Materials Science Citation Index'. Back volumes of $M R S$ Bulletin are available in $16 \mathrm{~mm}$ microfilm, $35 \mathrm{~mm}$ microfilm, or $105 \mathrm{~mm}$ microfiche through University Microfilms Inc., 300 North Zeeb Road, Ann Arbor, Michigan 48106.

\section{Materials Research Society} 9800 McKnight Road Pittsburgh, PA 15237-6006

Tel. (412) 367-3003; Fax (412) 367-4373 http://www.mrs.org/

\section{M|RIS BULLETIN}

Editorial Office • 9800 McKnight Road • Pittsburgh, PA 15237-6006

Tel. (412) 367-3004 x522; fax (412) 367-4373; http://www.mrs.org/

Editor

E.L. Fleischer

Managing Editor

J. Meiksin

Assistant Editor

L.R. Gallagher

Art Director

C. Love

Design/Production

T. Aiello and S. Franklin

Editorial Assistants

J. Dininny and

M. Wilmoth
Advertising

M.E. Kaufold

Circulation

B.J. Alcorn

Guest Editors

T.E. Matikas and R.L. Crane

Special Contributors

S. Diol, J. Guenther

E. Korenic, J.M. Phillips,

and L.A. Snyder

Special Consultant

M. Goodway

\author{
Associate Editor-Europe \\ I.W. Boyd \\ University College London \\ Dept. of Electronic and \\ Electrical Engineering \\ Torrington Place \\ London WCI E7 JE, U.K. \\ Tel. 44-171-380-7300 or 7302 \\ Book Review Editor \\ C.J. McHargue \\ University of Tennessee \\ Knoxville, Tennessee
}

MRS Office of Public Affairs

555 13th Street NW, Suite 900 East

Washington, DC 20004

Tel. (202) 383-8809, Fax (202) 383-8877

CHAIR-EDITORIAL BOARDS

E.N. Kaufmann • Argonne National Laboratory • Argonne, Ilinois, USA

\section{INTERNATIONAL ADVISORYBOARD}

M. Balkanski

University of Pierre and Marie Curie

Paris, France

R.G. Elliman

Australian National University

Canberra, Australia

S. Hsu

Chung Shan Institute of Science

and Technology, Retired

Taiwan, China

\section{TECHNICAL EDITORIAL BOARD}

\section{J.C. Bravman}

Stanford University

Stanford, California, USA

C.W. Draper

AT\&T Engineering Research Center

Princeton, New Jersey, USA

E. Fogarassy

Centre de Recherches Nucléaires

Strasbourg, France

\section{L.C. Ianniello}

U.S. Department of Energy, Retired Washington, DC, USA

$\mathrm{H}$-D. Lì

National Science Foundation-China

Beijing, China

P. Rama Rao

Ministry of Science and Technology

New Delhi, India
R. Roy

The Pennsylvania State University University Park, Pennsylvania, USA

T. Sugano

Toyo University

Tokyo, Japan
F.Y. Fradin

Argonne National Laboratory

Argonne, Illinois, USA

B.M. León

Universidad de Vigo

Vigo, Spain

G.L. Liedl

Purdue University

West Lafayette, Indiana, USA

\section{S. Namba}

Nagasaki Institute of Applied Science

Tokyo, Japan

A.D. Romig Jr.

Sandia National Laboratories

Albuquerque, New Mexico, USA

J. Soares

Universidade de Lisboa

Lisboa, Portugal

K.C. Taylor

General Motors R\&D Center

Warren, Michigan, USA

\section{MRS BULLETIN PUBLICATIONS SUBCOMMITTEE}

M. Nastasi, Chair

Los Alamos National Laboratory

Los Alamos, New Mexico

F.W. Clinard

Los Alamos National Laboratory

Los Alamos, New Mexico

R.C. Ewing

University of New Mexico

Albuquerque, New Mexico

Rensselaer Polytechnic Institute

Troy, New York

A.J. Hurd

Sandia National Laboratories

Albuquerque, New Mexico

M. Libera

Stevens Institute of Technology

Hoboken, New Jersey

\section{F. Shapiro}

Drexel University

Philadelphia, Pennsylvania

C.W. White

Oak Ridge National Laboratory

Oak Ridge, Tennessee

\section{MRS EXECUTIVE COMMITTEE}

\section{President}

C.V. Thompson

Massachusetts Institute of Technology

First Vice President and President-Elect

R. Hull

University of Virginia

Second Vice President and

Vice President-Elect

R.J. Nemanich

North Carolina State University

\section{Secretary}

K.S. Jones

University of Florida

Treasurer

A.K. Hays

Sandia National Laboratories

Immediate Past President

J.M. Phillips

Sandia National Laboratories

\section{Councillors}

R. Gibala

University of Michigan

A.I. Taub

Ford Research Laboratory

Executive Director

Materials Research Society

John B. Ballance

\section{INTERNATIONAL UNION OF MATERIALS RESEARCH SOCIETIES}

President

M. Doyama

Nishi-Tokyo University

Tokyo, Japan
Vice President

R.C. Ewing

University of New Mexico

Albuquerque, New Mexico USA
Treasurer

G.M. Crean

University College

Cort, Ireland

Immediate Past President

P. Siffert

Centre de Recherches Nucléaires

Strasbourg, France 